\title{
Tolerance of Three Juniper Species to Glyphosate
}

\author{
M.A. Czarnota ${ }^{1,2}$
}

ADDITIONAL INDEX wORDs. herbicide, N-(phosphonomethyl)glycine

SUMMARY. Glyphosate traditionally has been used by growers and landscapers as a nonselective herbicide; however, selective uses do exist. The use of glyphosate to control weeds in dormant and actively growing bermudagrass (Cynodon dactylon) is an example of selective weed control. Several ornamentals, including conifer species, have been known to exhibit good tolerance to over-the-top applications of glyphosate. Unfortunately, little published information exists on rates of glyphosate that may be used on specific ornamental species. The objective of this research was to determine the tolerance levels of three juniper species ['Blue Pacific' shore juniper (Juniperus conferta), 'Blue Star' juniper (Juniperus squamata), and 'Parsoni' juniper (Juniperus davurica)] to various rates of glyphosate. Research conducted in 2004 and 2005 indicated that injury to three juniper species did not exceed $23 \%$ with glyphosate rates up to $2.5 \mathrm{lb} /$ acre.

G rowers and landscapers are often faced with weed problems in ornamentals that cannot be controlled with selective herbicides. In landscape situations, glyphosate is mainly used as a nonselective herbicide. However, researchers have reported that many plants have significant tolerance to over-thetop applications of glyphosate when applied at rates between 0.1 and 2.0 lb/acre (Ahrens, 1974; Altland et al., 2002; Bing, 1974; Butler and Burnside, 1983; Derting et al., 1973; Olinger, 1982; Perry and Knowles, 1979; Putnum, 1976; Self, 1978). Also, Neal and Skroch (1985) determined that damage from glyphosate applications could be influenced by the time of year and growth stage of the treated plant. Moreover, Neal and Skroch also indicated that shore juniper absorbed carbon-14-labeled glyphosate during shoot elongation, but no significant absorption of glyphosate occurred when applications were made to shore juniper that were cold acclimated, winter dormant, at budbreak, or at termination of first flush of growth. Although risk is of plant damage is a concern, growers and landscapers have considerable interest in determining if glyphosate applications can be used on select plant material to remove problem weeds. The objective of this research

${ }^{1}$ Assistant Professor of Horticulture, Department of Horticulture, University of Georgia, College of Agricultural and Environmental Sciences, Griffin, GA 30292

${ }^{2}$ Corresponding author. E-mail: mac@griffin.uga.edu. was to determine the highest rate of glyphosate that three different species of juniper could tolerate when glyphosate treatments were applied after the termination and maturity of the first flush of growth.

\section{Materials and methods}

In Apr. 2004 and 2005, $2 \times$ 2 -inch liners of 'Blue Pacific' shore juniper, 'Blue Star' juniper, and 'Parsoni' juniper were potted into l-gal pots using potting mix (Fafard 52; Fafard, Agawam, MA). Plants were then placed on a gravel pad in the full sun, top-dressed with $18 \mathrm{~g}$ of Osmocote Pro (13N-5.7P-10.8K; The Scotts Co., Marysville, $\mathrm{OH}$ ), and irrigated with $\approx 0.5$ inch of water twice daily. Plants were maintained weed free up to initiation of the experiment in 2004 and 2005. Glyphosate treatments were applied on 29 May 2004 and 13 May 2005. Rates of glyphosate were $0.5,1.0,2.5,5.0$, and 10.0 $\mathrm{lb} / \mathrm{acre}$. The glyphosate applied was RoundupPro (Monsanto, St. Louis) which contains $4.0 \mathrm{lb} /$ gal glyphosate in the form of its isopropylamine salt. This formulation of glyphosate contains a proprietary blend of surfactants. For each treatment, 12 containers were placed in a $6 \times 6-\mathrm{ft}$ area. Glyphosate treatments were then applied, and containers were moved to assigned test areas where they were arranged in a randomized complete block design. Each treatment contained four replications, and each replication contained three subsamples. Treatments were allowed to dry for $\approx 12 \mathrm{~h}$ before first irrigation event. Glyphosate was applied with a carbon dioxide backpack sprayer calibrated to deliver $20 \mathrm{gal} / \mathrm{acre}$.

Visual injury symptoms were recorded at 4,8 , and 12 weeks after treatment (WAT). Juniper injury ratings were on a 0 to 100 scale, where $0=$ no apparent injury, 1 to $40=$ slight injury with some yellowing/discoloration, 40 to $60=$ definite juniper injury with noticeable discoloration or phytotoxicity, 60 to $99=$ severe injury with discoloration and necrosis, and $100=$ dead juniper with no evidence of regrowth.

At the termination of both studies, shoot biomass was collected from each treatment. Juniper shoot material from each treatment was cut at medium surface and dried at $70{ }^{\circ} \mathrm{C}$ for about $3 \mathrm{~d}$ to remove moisture. Dried shoots were weighed, and the average of the three subsamples was analyzed.

Data were analyzed using analysis of variance and means were subjected to Fisher's least significant difference test with a significance level of $\alpha \leq 0.05$. Tests for interaction between treatment and data were highly significant $(P \leq 0.0001)$; thus, treatment data were presented separately for both years. Although this was a quantitative study, use of regression was not used because the major concern of the study was the response of juniper at select rates. Also, rates were never high enough to kill any of the juniper species tested, a consulting statistician indicated that dose-response regression

\begin{tabular}{llll}
\hline $\begin{array}{l}\text { Units } \\
\begin{array}{l}\text { To convert U.S. to SI, } \\
\text { multiply by }\end{array}\end{array}$ & U.S. unit & SI unit & $\begin{array}{l}\text { To convert SI to U.S., } \\
\text { multiply by }\end{array}$ \\
\hline 0.3048 & $\mathrm{ft}$ & $\mathrm{m}$ & 3.2808 \\
3.7854 & $\mathrm{gal}$ & $\mathrm{L}$ & 0.2642 \\
9.3540 & gal/acre & $\mathrm{L} \cdot \mathrm{ha}^{-1}$ & 0.1069 \\
2.54 & inch $(\mathrm{es})$ & $\mathrm{cm}$ & 0.3937 \\
1.1209 & $\mathrm{lb} / \mathrm{acre}$ & $\mathrm{kg} \cdot \mathrm{ha}^{-1}$ & 0.8922 \\
28.3495 & $\mathrm{oz}$ & $\mathrm{g}$ & 0.0353 \\
$\left({ }^{\circ} \mathrm{F}-32\right) \div 1.8$ & ${ }^{\circ} \mathrm{F}$ & ${ }^{\circ} \mathrm{C}$ & $\left(1.8 \times{ }^{\circ} \mathrm{C}\right)+32$
\end{tabular}


analysis was not appropriate. Orthogonal contrasts were performed for linear and quadratic trends between damage and herbicide rate and are presented.

\section{Results and discussion}

2004 Expt. No significant damage was observed for any of the three juniper species at 0.5 or $1.0 \mathrm{lb} /$ acre glyphosate (Tables 1-3). However, at 5.0 and $10.0 \mathrm{lb} /$ acre glyphosate, significant damage was observed on all three juniper species during all rating dates (Tables 1-3). No significant injury was noted on 'Blue Pacific' shore juniper with glyphosate at 2.5 lb/acre. Damage with glyphosate at $2.5 \mathrm{lb} /$ acre to 'Blue Star' juniper and 'Parsoni' juniper varied throughout the rating periods (Tables $1-3$ ). There was no significant difference in dry weights between the glyphosate treatments and the nontreated control with 'Blue Pacific' shore juniper and 'Blue Star' juniper (Table 1 and 2). Dry weights with 'Parsoni' juniper at $0.5,5.0$, and $10.0 \mathrm{lb} /$ acre were significantly less than the nontreated control (Table 3 ).

2005 Expт. No significant visual damage was observed for any of juniper species at $0.5 \mathrm{lb} /$ acre glyphosate (Tables 1-3). Also, no significant injury was recorded to 'Blue Pacific' shore juniper at $1.0 \mathrm{lb} /$ acre glyphosate, but injury was significant at all rating dates at $10 \mathrm{lb} /$ acre glyphosate (Table 1). Injury to 'Blue Pacific' shore juniper at 2.5 and $5.0 \mathrm{lb} /$ acre glyphosate varied depending on rating date. With 'Blue Star' juniper, no significant injury was recorded with $0.5 \mathrm{lb} /$ acre glyphosate. Significant visual injury was recorded at all rating dates to 'Blue Star' juniper at 1.0, 2.5, 5.0 , and $10.0 \mathrm{lb} /$ acre glyphosate (Table 2). Visual damage ratings to 'Parsoni' juniper was significant with $2.5,5.0$, and $10.0 \mathrm{lb} /$ acre glyphosate at all rating dates, and ranged from $17 \%$ to $40 \%$ (Tables 3 ). Injury to 'Parsoni' juniper at $1.0 \mathrm{lb} /$ acre glyphosate varied depending on rating date. With 'Blue Pacific' shore juniper, no treatment reduced shoot dry weights compared with the nontreated control plants. However, with 'Blue Pacific' shore juniper, $0.5 \mathrm{lb} /$ acre glyphosate had a significantly

Table 1. Injury rating of 'Blue Pacific' juniper from glyphosate treatments in 2004 and 2005.

\begin{tabular}{|c|c|c|c|c|c|c|c|c|}
\hline \multirow{2}{*}{$\begin{array}{l}\text { Glyphosate rate } \\
(\mathrm{lb} / \text { acre })^{\mathrm{y}}\end{array}$} & \multicolumn{4}{|c|}{ Injury rating $2004(0-100 \text { scale })^{\mathrm{z}}$} & \multicolumn{4}{|c|}{ Injury rating 2005 (0-100 scale) } \\
\hline & 4 WAT $^{x}$ & 8 WAT & 12 WAT & Dry wt $(g)^{w}$ & 4 WAT & 8 WAT & 12 WAT & Dry wt $(g)^{w}$ \\
\hline 0.5 & $0 c^{v}$ & $0 \mathrm{c}$ & $0 \mathrm{c}$ & $84 \mathrm{a}$ & $2 \mathrm{c}$ & $0 \mathrm{c}$ & $3 \mathrm{bc}$ & $94 \mathrm{a}$ \\
\hline 2.5 & $3 c$ & $5 \mathrm{bc}$ & $8 \mathrm{bc}$ & $76 \mathrm{a}$ & $23 \mathrm{ab}$ & $10 \mathrm{~b}$ & $7 \mathrm{bc}$ & $61 \mathrm{c}$ \\
\hline 5.0 & $10 \mathrm{~b}$ & $8 \mathrm{~b}$ & $11 \mathrm{~b}$ & $74 \mathrm{a}$ & $13 \mathrm{abc}$ & $27 \mathrm{a}$ & $17 \mathrm{~b}$ & $60 \mathrm{c}$ \\
\hline 10 & $17 \mathrm{a}$ & $20 \mathrm{a}$ & $37 \mathrm{a}$ & $75 \mathrm{a}$ & $27 \mathrm{a}$ & $17 \mathrm{~b}$ & $33 \mathrm{a}$ & $66 \mathrm{bc}$ \\
\hline & $\mathrm{L}^{* * *}$ & $\mathrm{~L}^{* * *}$ & $\mathrm{~L}^{* * *}$ & NS & $\mathrm{L}^{* * *}$ & $\mathrm{~L}^{* *}$ & $L^{* *}$ & NS \\
\hline
\end{tabular}

${ }^{2}$ Visual injury ratings on a 0 to 100 scale where $0=$ no injury, 1 to $40=$ slight injury with some yellowing /discoloration, 40 to $60=$ definite juniper injury with noticeable discoloration or phytotoxicity, 60 to $99=$ severe injury with discoloration and necrosis, and $100=$ dead juniper with no evidence of regrowth.

y $1 \mathrm{lb} /$ acre $=1.1209 \mathrm{~kg} \cdot \mathrm{ha}^{-1}$.

${ }^{x}$ WAT $=$ weeks after treatment.

${ }^{\mathrm{w}} \mathrm{l} \mathrm{g}=0.0353 \mathrm{oz}$.

"Means within a column followed by the same letter are not significantly different at $\alpha=0.05$ as determined by Fisher's LSD test.

UTC $=$ untreated control.

LSD $=$ least significant difference .

$\mathrm{L}$ represents linear responses within rating date.

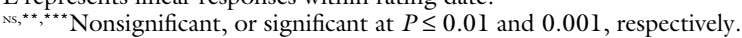

Table 2. Injury rating of 'Blue Star' juniper from glyphosate treatments in 2004 and 2005.

\begin{tabular}{|c|c|c|c|c|c|c|c|c|}
\hline \multirow{2}{*}{$\begin{array}{l}\text { Glyphosate rate } \\
(\text { lb/acre })^{y}\end{array}$} & \multicolumn{4}{|c|}{ Injury rating $2004(0-100 \text { scale })^{\mathrm{z}}$} & \multicolumn{4}{|c|}{ Injury rating 2005 (0-100 scale) } \\
\hline & 4 WAT $^{x}$ & 8 WAT & 12 WAT & Dry wt $(g)^{\mathrm{w}}$ & $4 \mathrm{WAT}$ & 8 WAT & 12 WAT & Dry wt $(g)^{w}$ \\
\hline 0.5 & $0 c^{v}$ & $0 \mathrm{c}$ & $0 \mathrm{c}$ & $133 \mathrm{a}$ & $0 \mathrm{c}$ & $0 \mathrm{~b}$ & $0 \mathrm{~d}$ & $180 \mathrm{a}$ \\
\hline 1.0 & $0 \mathrm{c}$ & $0 \mathrm{c}$ & $0 \mathrm{c}$ & $117 \mathrm{ab}$ & $10 \mathrm{~b}$ & $10 \mathrm{a}$ & $10 \mathrm{c}$ & $165 \mathrm{a}$ \\
\hline 2.5 & $17 \mathrm{~b}$ & $5 \mathrm{bc}$ & $13 \mathrm{c}$ & $100 \mathrm{~b}$ & $10 \mathrm{~b}$ & $13 \mathrm{a}$ & $10 \mathrm{c}$ & $126 \mathrm{~b}$ \\
\hline 5.0 & $27 \mathrm{~b}$ & $17 \mathrm{~b}$ & $33 \mathrm{~b}$ & $97 \mathrm{~b}$ & $17 \mathrm{ab}$ & $17 \mathrm{a}$ & $17 \mathrm{~b}$ & $123 \mathrm{~b}$ \\
\hline 10 & $70 \mathrm{a}$ & $60 a$ & $60 \mathrm{a}$ & $112 \mathrm{ab}$ & $20 \mathrm{a}$ & $17 \mathrm{a}$ & $27 \mathrm{a}$ & $101 \mathrm{c}$ \\
\hline & $\mathrm{L}^{* * *}$ & $\mathrm{~L}^{* *}$ & $\mathrm{~L}^{* * *}$ & NS & $\mathrm{L}^{* *}$ & $\mathrm{~L}^{*}$ & $\mathrm{~L}^{* * *}$ & $\mathrm{~L}^{* *}$ \\
\hline
\end{tabular}

${ }^{2}$ Visual injury ratings on a 0 to 100 scale where $0=$ no injury, 1 to $40=$ slight injury with some yellowing / discoloration, 40 to $60=$ definite juniper injury with noticeable discoloration or phytotoxicity, 60 to $99=$ severe injury with discoloration and necrosis, and $100=$ dead juniper with no evidence of regrowth.

${ }^{y} 1 \mathrm{lb} / \mathrm{acre}=1.1209 \mathrm{~kg} \cdot \mathrm{ha}^{-1}$.

WAT $=$ weeks after treatment.

${ }^{\mathrm{w}} 1 \mathrm{~g}=0.0353 \mathrm{oz}$.

"Means within a column followed by the same letter are not significantly different at $\alpha=0.05$ as determined by Fisher's LSD test.

$\mathrm{UTC}=$ untreated control.

LSD $=$ least significant difference.

$\mathrm{L}$ represents linear responses within rating date.

Ns,,,$^{* * *, * * *}$ Nonsignificant or significant at $P \leq 0.5,0.01$, and 0.001 , respectively. 
Table 3. Injury rating of from 'Parsoni' juniper glyphosate treatments in 2004 and 2005.

\begin{tabular}{|c|c|c|c|c|c|c|c|c|}
\hline \multirow{2}{*}{$\begin{array}{l}\text { Glyphosate rate } \\
(\text { lb/acre })^{y}\end{array}$} & \multicolumn{4}{|c|}{ Injury rating $2004(0-100 \text { scale })^{\mathrm{z}}$} & \multicolumn{4}{|c|}{ Injury rating 2005 (0-100 scale) } \\
\hline & ${\overline{4 \text { WAT }^{\mathrm{x}}}}$ & 8 WAT & 12 WAT & Dry wt $(g)^{w}$ & $4 \mathrm{WAT}$ & 8 WAT & 12 WAT & Dry wt $(g)^{w}$ \\
\hline 0.5 & $0 c^{v}$ & $0 \mathrm{c}$ & $0 \mathrm{c}$ & $51 \mathrm{bc}$ & $5 \mathrm{~cd}$ & $0 \mathrm{c}$ & $0 \mathrm{~d}$ & $61 \mathrm{ab}$ \\
\hline 2.5 & $0 \mathrm{c}$ & $17 \mathrm{c}$ & $23 \mathrm{~b}$ & $53 \mathrm{ab}$ & $17 \mathrm{bc}$ & $23 \mathrm{ab}$ & $17 \mathrm{bc}$ & $49 \mathrm{bc}$ \\
\hline 5.0 & $13 \mathrm{~b}$ & $37 \mathrm{~b}$ & $43 \mathrm{~b}$ & $36 \mathrm{~cd}$ & $27 \mathrm{ab}$ & $40 \mathrm{a}$ & $27 \mathrm{ab}$ & $38 \mathrm{~cd}$ \\
\hline 10 & $50 \mathrm{a}$ & $77 \mathrm{a}$ & $93 \mathrm{a}$ & $31 \mathrm{~d}$ & $37 \mathrm{a}$ & $40 \mathrm{a}$ & $37 \mathrm{a}$ & $28 \mathrm{~d}$ \\
\hline & $\mathrm{L}^{* * *}$ & $\mathrm{~L}^{* * *}$ & $\mathrm{~L}^{* * *}$ & $\mathrm{~L}^{* * *}$ & $\mathrm{~L}^{* *}$ & $\mathrm{~L}^{* * *}$ & $\mathrm{~L}^{* *}$ & $\mathrm{~L}^{* *}$ \\
\hline
\end{tabular}

${ }^{2}$ Visual injury ratings on a 0 to 100 scale where $0=$ no injury, 1 to $40=$ slight injury with some yellowing/discoloration, 40 to $60=$ definite juniper injury with noticeable discoloration or phytotoxicity, 60 to $99=$ severe injury with discoloration and necrosis, and $100=$ dead juniper with no evidence of regrowth.

${ }^{y} 1 \mathrm{lb} /$ acre $=1.1209 \mathrm{~kg} \cdot \mathrm{ha}^{-1}$

${ }^{x}$ WAT $=$ weeks after treatment

${ }^{\mathrm{w}} 1 \mathrm{~g}=0.0353 \mathrm{oz}$.

${ }^{\vee}$ Means within a column followed by the same letter are not significantly different at $\alpha=0.05$ as determined by Fisher's LSD test.

UTC $=$ untreated control.

LSD = least significant difference.

$\mathrm{L}$ represents linear responses within rating date.

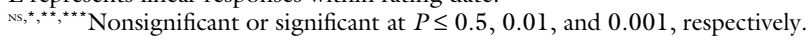
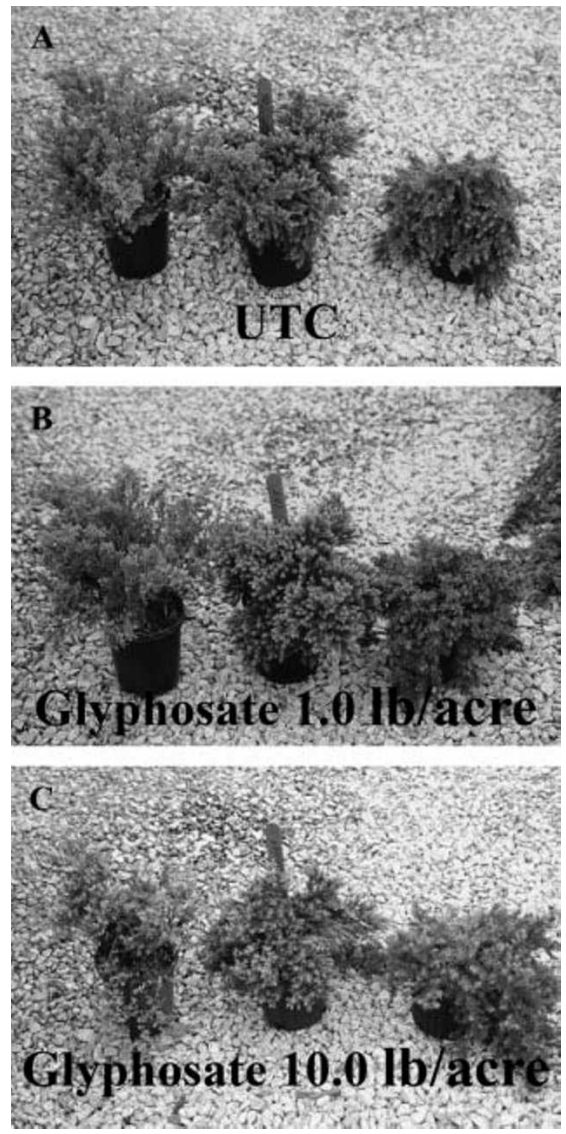

Fig. 1. The response of three juniper species ( $A$ = 'Parsoni' juniper, $B$ = 'Blue Star' juniper, and C = 'Blue Pacific' shore juniper) to a 1.0 and $10.0 \mathrm{lb} /$ acre (1.12 and $11.21 \mathrm{~kg} \cdot \mathrm{ha}^{-1}$, respectively) rate of glyphosate at 12 weeks after treatment compared with the untreated control (UTC) in 2005. higher weight than the nontreated control (Tables 1). Dry weights of 'Parsoni' and 'Blue Star' juniper were significantly less than the nontreated control with $2.5,5.0$, and $10.0 \mathrm{lb} /$ acre glyphosate.

Orthogonal contrasts were performed for linear and quadratic trends between damage and herbicide rate. The 2004 and 2005 data showed significant linear trends with all juniper species at all rating dates (Table $1-$ $3)$. Not surprisingly, linear trends support the means separation data and the fact that as glyphosate rate increased damage to the juniper plants increased.

During 2004 and 2005, no significant injury was recorded to either of the juniper species with $0.5 \mathrm{lb} / \mathrm{acre}$ glyphosate. Moreover, injury ratings for all three juniper species did not exceed $23 \%$ with glyphosate rates up to $2.5 \mathrm{lb} /$ acre. This rate of glyphosate (as well lower rates) could be used to control a vast number of weed species (Monsanto Co., 2003). 'Parsoni' juniper appeared to be the most sensitive to the increase in glyphosate concentrations (Fig. 1). With conifers, it is still unclear what mechanism is responsible for the high tolerance to glyphosate. Neal and Skroch (1985) indicated that plant growth stage was important in a plants' tolerance to glyphosate, but several groups have indicated that epicuticular waxes, cuticle size, and the presence of stomates and trichomes on the adaxial leaf surface can influence glyphosate absorption (Norsworthy et al., 2001; Wyrill and Burnside,
1976). Others indicate that there may be differences at the molecular level, with higher activity of the 5enolpyruvylshikimate-3-phosphate synthase, which glyphosate is responsible for inhibiting (Westwood and Weller, 1997). Further research is needed to better understand the reason for this elevated glyphosate tolerance.

\section{Conclusion}

Currently, the use of glyphosate over-the-top of ornamentals is an offlabel use. With field- and containergrown ornamentals, many weed control situations are often encountered where no selective herbicides are available. In these situations, low rates of glyphosate have the potential to provide a low-cost cleanup and rescue treatment of weed-infested ornamentals. From this research, it appears that the three juniper species tested in this study were tolerant to glyphosate rates as high as $2.5 \mathrm{lb} /$ acre. Glyphosate rates above $2.5 \mathrm{lb} /$ acre caused unacceptable damage. However, growers should use caution in applying glyphosate to nursery crops and should conduct trials before treating their entire stock.

\section{Literature cited}

Ahrens, J.F. 1974. Selectivity of glyphosate and asulam in ornamental plantings and Christmas trees. Northeast Weed Sci. Soc. 28:361-368.

Altland, J.E., C.H. Gilliam, and J.W. Olive. 2002. Postemergence prostrate spurge (Chamaesyce prostrata) control in 


\section{Research Reports}

container-grown liriope. J. Environ. Hort. 20(1):41-46.

Bing, A. 1974. Glyphosate on ornamentals. Northeast Weed Sci. Soc. 28:369371.

Butler, D.D. and O.C. Burnside. 1983. Effects of spray components on glyphosate toxicity to annual grasses. Weed Sci. 31:124-130.

Derting, C.W., J.O.N. Andrews, R.G. Duncan, and K.R. Frost. 1973. Two years of perennial weed control investigations with glyphosate. Southern Weed Sci. Soc. 26:44-50.

Monsanto Co. 2003. Roundup pro label. Monsanto Co., St. Louis.
Neal, J. and W. Skroch. 1985. Effects of timing and rate of glyphosate application on toxicity to select woody ornamentals. J. Amer. Soc. Hort. Sci. 110:860864.

Norsworthy, J.K., N.R. Burgos, and L.R. Oliver. 2001. Differences in weed tolerance to glyphosate involve different mechanisms. Weed Technol. 15:725-731.

Olinger, H.L. 1982. How do you spell release. Southern Weed Sci. Soc. 35:216223.

Perry, F.B.J. and J.W. Knowles. 1979. Potential of glyphosate for weed control in containers. Southern Nursery Assn. Res. Conf. 24:253-254.
Putnum, A.R. 1976. Fate of glyphosate in deciduous fruit trees. Weed Sci. 24:425430.

Self, R.L. 1978. Foliar applications of Roundup to 18 container grown ornamentals. Southern Nursery Assn. Res. Conf. 23:166-187.

Westwood, J.H. and S.C. Weller. 1997. Cellular mechanisms influence differential glyphosate sensitivity in field bindweed (Convolvulus arvensis). Weed Sci. 45:2-11.

Wyrill, J.B. and O.C. Burnside. 1976. Absorption, translocation, and metabolism of 2,4-D and glyphosate in common milkweed and hemp dogbane. Weed Sci. 24:557-566. 